\title{
STUDENT VIEWS OF CONCEPT MAPPING USE IN INTRODUCTORY TERTIARY BIOLOGY CLASSES
}

\begin{abstract}
Introductory tertiary level science classes (i.e., at the university or postcompulsory school level) including those for biology face increasing diversity in intake. Previous research has indicated university level teachers assume a certain level of prior knowledge which may or may not be possessed by such students. This report focuses on the use of concept mapping in introductory biology tutorial classes. The research findings suggest that the students found the use of concept mapping enjoyable and that it can enhance meaningful learning for topics that require students to link concepts.
\end{abstract}

KEY WORDS: concept mapping, introductory biology, prior knowledge, tertiary level

\section{INTRODUCTION}

\section{Student Diversity in Introductory Science at the Tertiary Level}

In the middle of the twentieth century, access to, and participation in, tertiary education (i.e., post-compulsory school level, typical age range 18-19 years for introductory courses) was limited to certain segments of the population, often students from a wealthy background or young people with educated parents. More recently increasing demand for a higher skilled workforce in most Western countries and in many developing countries led to increased enrolments in post-compulsory education (Laws, 1996). Technological advances and the globalization of technology means that demand for tertiary education has been particularly heavy for the sciences, engineering and technology-related fields although this has reduced somewhat in recent times (Dalgety, Coll \& Jones, 2003). Fensham (1980) \& Kings (1990) pointed out that increased participation in tertiary level science has resulted in a shift in emphasis from education in science for specialists (i.e., scientists and engineers), to science education for a more diversified audience. This is in some part related to issues of scientific literacy, which Laugksch (2000) argues is now essential for all citizens. Although it might be argued that tertiary level education has always been for the specialist, recent changes to school curricula, including science (e.g., the introduction of technology as a separate subject, see Sade \& Coll, 2003), mean

\footnotetext{
$\star$ Author for correspondence.
} 
that students now have greater choice in school subjects and this, coupled with increased participation in tertiary science education, has resulted in increased diversity in entry-level or introductory science classes (Fensham, 1992; Laws, 1996).

Diversity in ethnicity and other demographic groups (e.g., females and mature students) in introductory science classes at tertiary level is not viewed negatively. Indeed, the opposite might well apply, with increasing calls for science participation among students from non-traditional backgrounds (see, e.g., Dearing, 1997). What is of concern is the increasing diversity in content knowledge of entry-level or freshman science students (Coll, 2000; Laws, 1996). The importance of students' prior knowledge is emphasized in a variety of current theories of learning, including constructivism and its variants (such as social and contextual constructivism, see Good, Wandersee \& St. Julien, 1993). Most tertiary level courses assume a certain amount of basic scientific knowledge in the discipline concerned (and in related disciplines such as mathematics).

\section{Student Prior Knowledge in Introductory Science at the Tertiary Level}

Constructivist-based views of learning argue that learners construct knowledge by relating new knowledge to relevant concepts that they already possess (e.g., Douvdevany, Dreyfus \& Jungwirth, 1997; Millar, 1989; Wandersee \& Fisher, 2000). During the learning process students may form understandings that are inconsistent with consensual scientific views or teaching models and concepts (Coll, France \& Taylor, 2005), particularly if the prerequisite knowledge necessary for the construction of a new concept is absent from their cognitive structure (Garnett, Garnett \& Hackling, 1995). Prior knowledge is thus considered to be important because it interacts with knowledge presented during formal instruction, sometimes resulting in undesirable outcomes such as alternative conceptions for important scientific concepts (Pfundt \& Duit, 1997, 2000; Wandersee, Mintzes \& Novak, 1994). Such alternative conceptions frequently make subsequent learning problematic as science understanding, and as a consequence teaching, builds on certain fundamental concepts in meaning-making and learning.

Recent research suggests that there are commonly differences between students' actual prior knowledge and the prior knowledge that faculty assume students possess for introductory tertiary level science (Buntting, Coll \& Campbell, 2004; Laws, 1996). Research also suggests that tertiary students struggle to make links between scientific concepts, even those they are familiar with from prior learning at secondary school 
(Buntting et al., 2004; Laws, 1996). Lack of ability to make appropriate connections between related scientific concepts may point to lack of coherence in students' cognitive structures (Taber, 1995, 1998), and the organization of concepts in students' minds, with students considering separate concepts to be isolated and unrelated (Brandt et al., 2001; Schmid \& Telaro, 1990). In order to understand science in the way desired by teachers and the scientific community, students therefore need particular content knowledge, and the ability to form links between related scientific concepts (Arnaudin, Mintzes, Dunn \& Shafer, 1984). They also need to be able to reorganize their prior knowledge in the light of new knowledge (Huai, 1997).

\section{Concept Mapping as a Pedagogical Tool}

A variety of pedagogical 'tools' are open to secondary school and tertiary level teachers to enhance student understanding of scientific concepts. For example, Coll (in press) and Coll et al. (2005) point out that the use of analogies and mental models can enhance student understanding of complex and abstract scientific conceptions (see also, Harrison \& Treagust, 1996, 1998). However, concept mapping has been reported to provide a very effective strategy to help students learn meaningfully by making explicit the links between scientific concepts (Adamczyk, Willson \& Williams, 1994; Fisher, Wandersee \& Moody, 2000; Novak \& Gowin, 1984). Concept mapping also has been reported to aid collaborative learning (Sizmur \& Osbourne, 1997), and to improve students' problem-solving ability (Okebukola, 1992). Although a large meta-analysis by Horton et al. (1993) showed that concept mapping generally had positive effects on both student achievement and attitudes, only six of the studies included in the review were concerned with biology and had been subjected to peer-review by publication in an educational journal. It seems that despite the considerable number of concept mapping references in the literature, the majority refers to concept mapping as a tool to identify students' knowledge structures. Very few studies have evaluated its use as a learning/teaching tool in tertiary biology courses (Heinze-Fry \& Novak, 1990; Smith \& Dwyer, 1995; Yarden, Marbach-Ad \& Gershani, 2004). Further, these studies generally involve very short-term exposure to concept mapping, one or two lessons at most. Here, we propose that the strategy is worthy of further investigation, particularly in the context of the increased diversity in entry-level university courses and the implications this has on the teaching and learning in these courses.

Concept maps are constructed by writing concepts in boxes and linking them by labeled lines. The labels are important because they 
require whoever is constructing the map to actively select appropriate linking words. The links need to be valid, in that they need to make sense, and to be genuine links between the two concepts. In other words, they need to relate the two concepts in some meaningful way that is in agreement with consensual scientific views. The links then help a reader (for example, the teacher) to make sense of the students' concept maps (Novak \& Gowin, 1984). Concept mapping also is a tool that enables gaps in knowledge and misunderstandings, that later might lead to alternative conceptions, to be identified and addressed (Willson \& Williams, 1996). In this way, concept maps can act not only as a pedagogical tool but as a means of formative assessment. In general, the greater the number of valid links between concepts, the more sophisticated the map is considered to be (Novak \& Gowin, 1984). The technique therefore focuses on conceptual organization and integration (Smith \& Dwyer, 1995) and gives students a way to explicitly link and organize concepts (White \& Gunstone, 1992).

\section{Student Learning and Assessment}

Before discussing our work, it is appropriate to consider an important feature of any educational setting, that of assessment of student learning. Tamir (1998) points out that the assessment processes used in science education are complex, and often contentious, issues. Gitomer \& Duschl (1998) argue that there are multiple stakeholders involved in assessment regimes, particularly at the school level. A number if these stakeholders, for example, school boards, employers, and parents, have called for better assessment processes that focus on deeper, more meaningful learning (Black 1998; Lomask, Baron \& Greig, 1998; Erickson \& Meyer, 1998). Intrinsic to this argument is a perceived link between pedagogies, students' learning strategies, and their perceptions of their assessment regimes (Gates, Augistine, Benjamin, Bikson, Kaganoff, Levy et al., 2002). In other words, students will use learning approaches, and teachers will uses pedagogies which will reward them within the context of the assessment practices present in their education setting.

Tamir (1998) argues that there have been significant shifts in assessment regimes at the compulsory school level worldwide. However, other authors note that at the post-compulsory school and tertiary levels little has changed in recent years (Coll, 2000; Laws, 1996). The work reported here is conducted in an environment of fairly conventional assessment processes, which typically reward rote learning and memorization, and pedagogies associated with such learning strategies. 


\section{RESEARCH AIMS AND OBJECTIVES}

The tertiary institution that forms the context for this work has, as reported elsewhere in the literature, faced increasing diversity in student intake into introductory biology classes (and - as might be expected - other science classes). Concern expressed by teaching faculty about difficulties in teaching introductory biology at the institution involved in this study stimulated interest in a potential means of helping new students cope with introductory biology course content. Related research (see Dalgety et al., 2003) points to the impact of learning experiences, some of which students find unappealing (such as highly didactic teaching styles), and other more interactive strategies which they find more appealing (Coll, 1997). Large-scale mass lectures common at the introductory level often do not provide opportunities for interactive or innovative pedagogies to enhance student learning. Hence, tutorials classes, which are smaller and at least potentially more interactive, were seen as the most appropriate educational vehicle. However, tutorials, despite their potential, are often teacher-driven and based around a series of pre-set questions (Dalgety et al., 2003). In an attempt to engage students in more meaningful learning, concept mapping was introduced as a teaching and learning tool in two of the six 50-min tutorial classes offered each week as part of two different entry-level biology courses. The other tutorial classes were run in the normal manner and consisted mostly of the tutor going through pre-set questions.

The intention of using a concept mapping teaching/learning strategy in tutorials in the present work was threefold: To encourage students to form explicit links between new concepts and concepts they already knew; to assist students with more limited prior knowledge to recognize and fill in any gaps in their prior knowledge; and to help students to become "active constructors of meaning" (Dawson, 1993, p. 74). The researchers were interested to see if the use of concept maps was appealing or a deterrent to students, and to gain some insights into the impact the use of concept maps had on student learning.

The research reported in this work thus sought to address two issues. First, we sought to understand students' perceptions of the use of concept maps as a teaching tool. This was deemed necessary since unfamiliar pedagogies have been reported to have a negative influence on tertiary level students who quickly become accustomed to lectures in which they can 'turn off' and become passive learners (Dalgety et al., 2003). Hence, a new teaching approach - whatever its potential learning benefits - needs to be introduced with caution. Second, we sought to evaluate student 
understanding of key biology concepts and to see if this was enhanced by the use of concept mapping in tutorial classes. The authors constantly strived to enhance validity and reliability of the findings as is presented in the methodology, and this is based on Trochim (1999).

\section{THEORETICAL FRAMEWORK}

This inquiry was conducted within an interpretive paradigm with a constructivist view of learning. Constructivism as a theory of learning has come to dominate much research in education and science education. Whilst there are many variants of constructivism (Good, Wandersee \& St. Julien 1993), there are several basic notions common to all forms. Constructivism posits that an individual is not a passive receiver of knowledge, but actively constructs meaning in his or her own mind. This construction of knowledge is influenced by many factors, but one of the most important factors is what the learner already knows about the topic under instruction, and also about other related topics that might impinge upon learning (Taber, 1995). This work was informed by a social-constructivist view of learning, in which learning is considered to be the construction of meaning by individuals in social settings (Guba \& Lincoln, 1994; Tobin 1993). This branch of constructivism draws on the work of Vygotsky (e.g., 1962) and the internal construction of knowledge is viewed as being driven primarily by social interaction (Wertsch, 1985) and ideally involves "negotiating understandings through dialogue or discourse shared by two or more members of a community of people who are pursuing shared goals" (Brophy, 2002, p. ix). In this context, the teacher's role is to act as a discussion leader, posing questions, seeking clarifications, promoting dialogue, and helping groups of students to recognize areas of consensus and continuing disagreement (Good \& Brophy, 2000). The students aim to make sense of new input by relating it to their prior knowledge and by collaborating in dialogue with others to co-construct shared understandings (Good \& Brophy, 2000).

Furthermore, whilst we have used a variety of tools, including quantitative instruments and analysis of the results of common topic tests, the study is not experimental in nature (see below). Rather, this study is exploratory and descriptive, seeking to uncover learners' experiences and to contextualize the work in the particular educational setting in which it was conducted. Hence, whether or not the findings are applicable in other educational settings is best judged by the reader (see Merriam, 2001; Peshkin, 1993). 


\section{MethodolOGY}

\section{Participant Description}

The research was carried out in two entry-level biology courses at a New Zealand university (termed introductory tertiary level in the New Zealand context). Students entering these courses now come from diverse academic backgrounds (see comments in, e.g., University of Waikato, 2004; Massey University, 2004). To illustrate, of the students enrolled in an entry-level biology course at the university where the research was carried out, only $48 \%{ }^{1}$ had completed Year 13 biology at secondary school (Year 13 is the end of secondary schooling and thus the highest level of secondary schooling in New Zealand). A further $10 \%$ had completed one first-year biology course at a tertiary education provider. Those who had not completed Year 13 biology or a tertiarylevel course had either completed a course in general science at Year 13 level (3\%), or biology or general science at the Year 11 or Year 12 levels (24\%). Ten percent of students were identified as 'mature students' (i.e., having completed their schooling five or more years prior to enrolling at university). The wide range of academic experiences and prior learning of the students therefore presents a challenge to teaching staff if they are to take into account students' prior knowledge.

Students in two entry-level courses were included as part of the study. The study was iterative in the sense that the two courses were not offered at the same time, and so the findings from the first course were used to inform the data collection in the second course, with the study incorporating a process of inquiry maturation (Guba \& Lincoln, 1994). Although focusing on different content, for example, plant and molecular biology, the two courses were similar in structure and pedagogy and included three 50-min lectures each week, as well as a weekly laboratory class, which is compulsory. The process of the lectures consisted of lecturers covering course content in a very didactic manner according to a transmission-based model of instruction.

In addition to the lectures and laboratory sessions, six tutorial sessions are offered each week. These run for $50 \mathrm{~min}$ and attendance is voluntary. Two of the sessions were set aside each week for teaching students to use concept mapping as a learning tool. The tutorials were advertised as usual during the first week of teaching, and students were told which tutorial classes had been set aside for teaching them 'a study technique that could be useful to their learning' (i.e., the concept mapping tutorials). The third author taught all of the concept mapping tutorials. 
The remaining tutorials were taught mostly by other tutors, or by the lecturer teaching the course at the time, and were more conventional in style, with the tutor or lecturer going over a list of pre-set questions made available to students in the course lecture notes.

A different cohort of students was enrolled in the two biology courses that were included in the study.

\section{Observations of Tutorials}

Unobtrusive observation of all lectures and four of the six weekly tutorials (two conventional and two concept mapping) were conducted throughout the 12 teaching weeks of both courses. The aim of the observations was to develop an understanding of the general conduct of both forms of tutorial classes (both concept mapping and conventional) as well as the course content covered prior to and during the tutorials. To this end, notes were made about the content of the lecture and tutorial sessions, as well as any interactions between the lecturer/tutor and students. Knowledge of content covered in tutorials was important for later analysis of student learning and the relevant tutor provided details of content covered in the two unobserved tutorials.

Although attendance at tutorials is voluntary, the students were asked at each tutorial, observed and not observed, to write their ID numbers on a sheet of paper for the purpose of the research. The students were assured that these details would not influence their assessment grades. Pseudonyms are used throughout this report.

\section{Survey of Student Perceptions of Concept Mapping as a Pedagogical Tool}

To answer the first research objective (i.e., to investigate students' perceptions of concept mapping), students were asked to provide feedback on their experiences in the tutorial classes that employed concept mapping. An open-ended questionnaire (Appendix A) was administered to students in one course, a course that covers topics in animal and plant biology. The responses to this questionnaire were analyzed thematically and are presented in the next session. The analysis was also used to develop a questionnaire incorporating Likert scales, which was administered to students in the second course; one which covered cellular and molecular biology (see Appendix B). In this way, more qualitative data was obtained from the first cohort of students, and more quantitative data was obtained from the second cohort. The 
response rate for both courses was $100 \%$ as a result of the captive nature of the administration. The validity of the instruments were enhanced by the use of follow-up interviews which probed students' responses to open-ended questions and confirmed that what had been written reflected their opinions about the tutorials.

\section{Analysis of Common Topic Tests}

To answer the second research objective (i.e., what influence concept mapping may have on student learning), data were collected from analysis of selected questions from course common tests administered to the whole class for traditional knowledge/comprehension level assessment purposes (see Table I). These questions were similar to ones used by lecturing staff in assessment tasks in previous years and the answers were likely to represent the students' best attempts.

The test questions were examined thematically and the researchers classified the questions into two types. One type of question, in the judgment of the researchers and teaching staff, could be answered by repetition of information provided in the course lecture notes (i.e. rote learning). For example, the questions were either very descriptive in nature (e.g., 'What is metagenesis?') or the information required to answer the question was provided directly in the course notes (e.g., to complete a diagram, also presented in the lecture notes, by filling in the appropriate terms). The second type of question consisted of questions that required students to have an understanding of a range of biological concepts, and to link these together in a novel way. An example of such a question is: "Briefly describe the maternal and paternal homologous chromosomes in terms of the DNA molecules and genes that they contain." At first sight such a question might also appear to be rewarded by rote learning. However, although each of these concepts had been introduced in lectures, the link between 'homologous chromosomes' as a concept and the relationship that this has with the positioning of genes along chromosomes had not been made explicit. Hence, students did need to be able to link concepts in order to answer such a question satisfactorily (as adjudged by the researchers and teaching staff). Other examples of these latter sorts of questions are provided in Table I.

Differences in performance in the common topic tests between students that completed the concept mapping tutorials and those who completed traditional tutorials were investigated using statistical means including the use of chi-square tests of independence. 


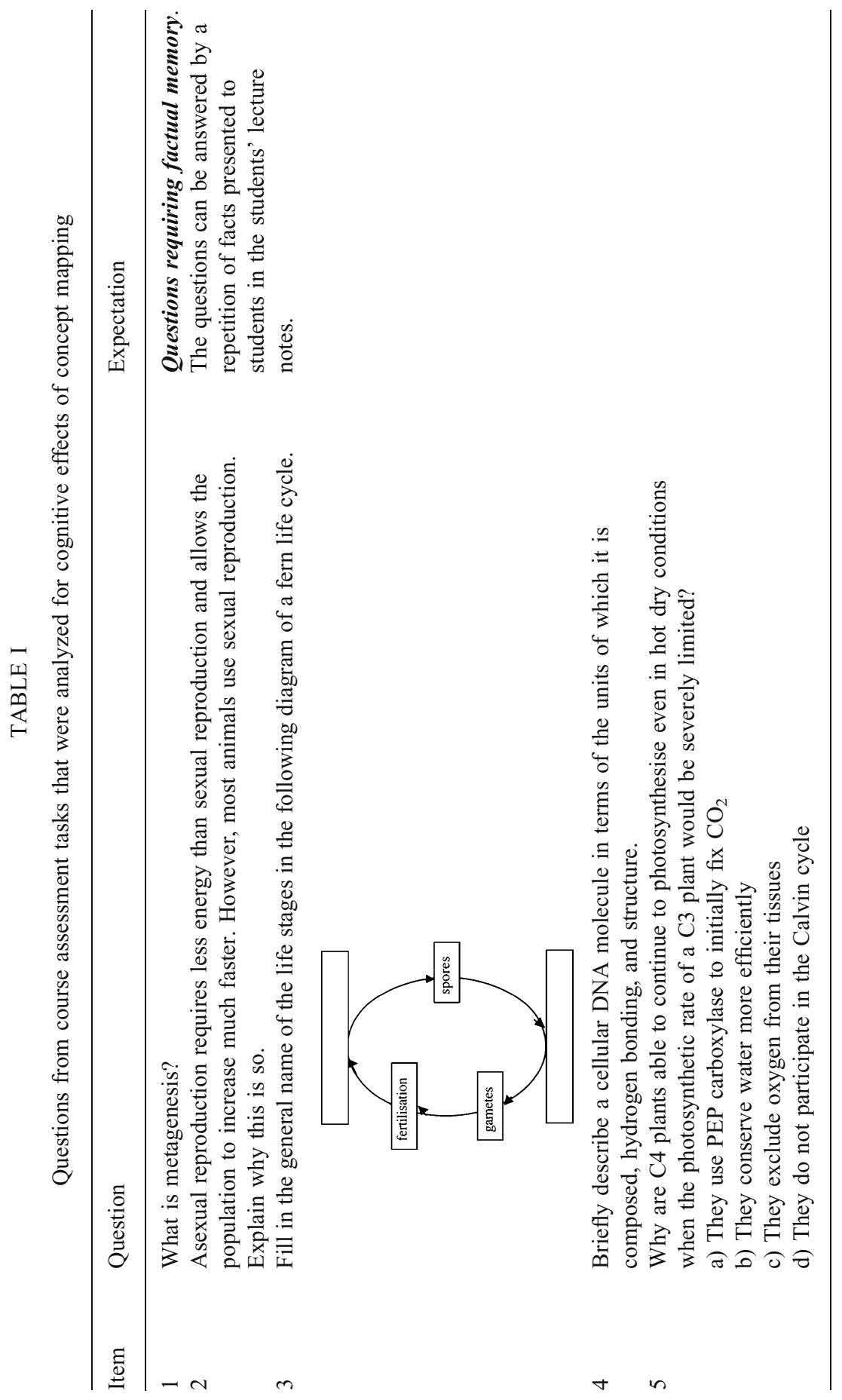


CONCEPT MAPPING USE IN INTRODUCTORY TERTIARY BIOLOGY CLASSES 651

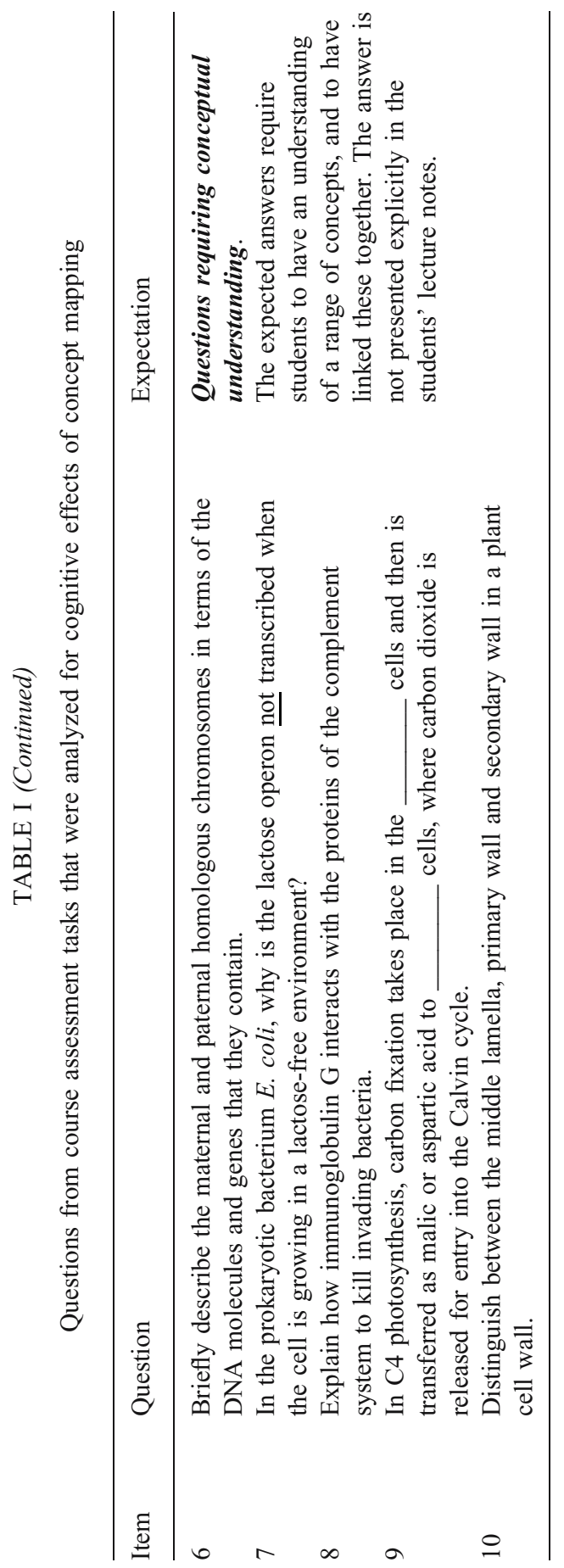




\section{RESEARCH FINDINGS}

\section{Classroom Observation of Tutorial Classes}

Student attendance at tutorials was voluntary and fluctuated from week to week, although there were no statistically significant differences in numbers attending concept mapping and conventional tutorial sessions. Approximately $50 \%$ of the student population in a class of just over 200 attended four or more tutorials during a 12-week teaching period, with $15 \%$ attending nine or more sessions. Students did not necessarily attend the same session each week.

In the conventional tutorials, discussion was driven primarily by a list of pre-set questions available to students in their lecture notes. The level of student input into the discussion seemed to be largely determined by the teaching style of the tutor, and ranged from being fairly interactive, where the tutor would ask students for the answers rather than giving them the answers; to very teacher-directed, where the tutor would write the answers up on the board with very little student input.

In the concept mapping tutorials, the potential benefits of concept mapping in learning science were presented during the first and second tutorial sessions, and the tutor modeled the construction of several different concept maps on the board. These maps were based on questions raised by students about topics that had been covered in the lectures, and the tutor used open-ended questions to encourage the class to contribute to the construction of the concept map. Once concept mapping had been modeled in this way, the students were encouraged to work as individuals or in groups to construct their own concept maps. Adhesive-backed notes were used during the concept mapping tutorials in the first few weeks until the students became familiar with the idea of concept mapping. A list of important concepts related to a relevant topic was created on an overhead transparency sheet and students were encouraged to write these down on their notes, and rearrange them to form a concept map (as per Kinchin, 2000). The list of concepts was generated by the tutor, in conjunction with student input. In later tutorial classes, students were encouraged to work as individuals or small groups to prepare concept maps on overhead transparency sheets. The topics for the concept maps were based on questions that the students had asked regarding content covered in earlier lectures (e.g., "Can we go over cell division?"). While students were constructing their concept maps, the tutor circulated around the class and used the time to discuss the concept mapping technique and/or student ideas with small groups of students. Students were also able to ask the tutor 
questions during this time. The completed overhead transparency sheets were then displayed and the tutor used them to facilitate whole-class discussion. In some tutorial classes, particularly those before common topic tests, the students arrived with a range of different questions to discuss, and rather than spending time on just one or two of these questions and getting students to construct their own concept maps, the tutor worked out a general concept map on the board, asking for input from the class about concepts to include and where they would fit. The concept mapping tutorials therefore included a mix of both teacher and studentgenerated maps. This approach was deemed appropriate since it is consistent with the social-constructivist nature of this study. As discussed above, a social constructivist view of learning posits that learning, whilst an individual activity in that each individual constructs meaning in his or her own mind, is carried out within a particular social context. The intention was to help students to co-construct knowledge in their own social setting, facilitated by the tutor as the more knowledgeable peer (Vygotsky, 1962).

The tutor running the concept mapping tutorials aimed to include student ideas in the construction of concept maps, and to encourage students to use the concept mapping approach to help students to form links between new concepts under instruction. An example of the dialogue between the tutor and the class is given below. The concept map that was constructed on the board during the conversation is presented in Figure 1 (shaded concepts relate directly to the discussion excerpt).

Student 1: I have a question about the cell wall and microfibrils - how can they bend? Tutor: Your question relates to the structure of the plant cell wall.

Student 1: I don't understand how they change their hydrogen bonds, and how they change their shape or something?

Tutor: What [the student] is referring to is the way that the primary cell wall can expand, allowing the cell to grow, but when the secondary cell wall is laid down then the shape of the cell becomes fixed. So let's think about cell walls [writing cell wall on the board]. What are they composed of?

Student 2: Cellulose.

Tutor: Good. What else? What holds it together?

Student 3: Peptidoglycan?

Tutor: No, that's found in bacterial cell walls. We're talking about plant cell walls.

Student 2: The gel matrix? [looking in course notes]

Tutor: Good. So there's the cellulose, which is held in place in the gel matrix [writes cellulose and gel matrix on the board and joins them to the cell wall concept using the linking term made of]. And it's the interactions between the two - the cellulose and the matrix - that give the cell wall its strength [adds chemical interactions and give strength to the developing concept map]. Now, what is the gel matrix made up of? 


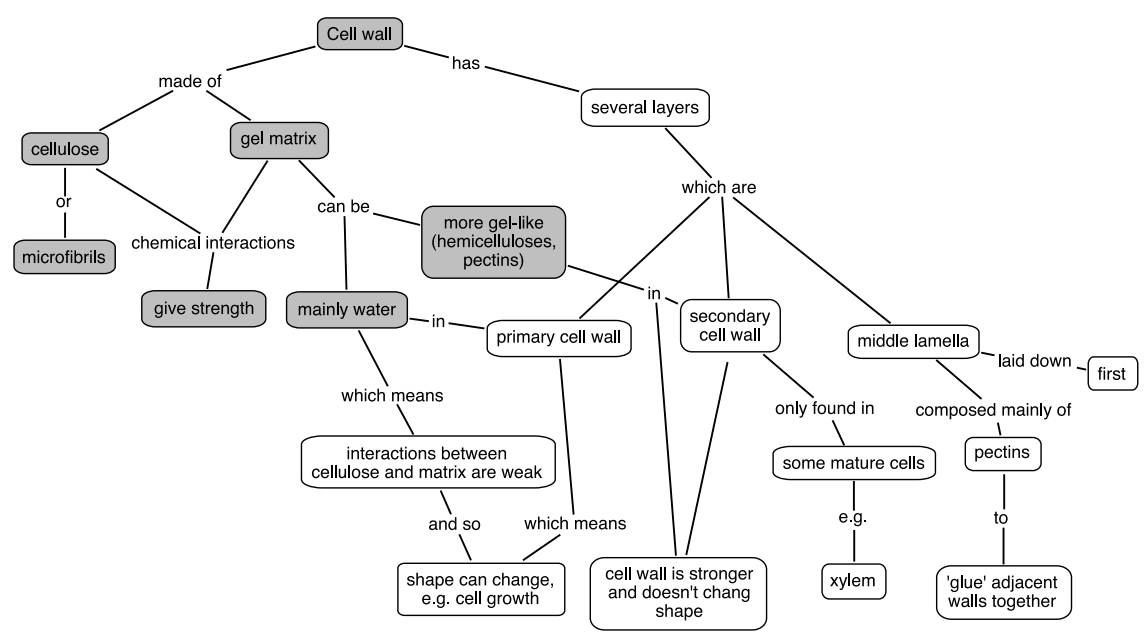

Figure 1. Concept map constructed by the tutor based on student responses to her guided questions.

Student 4: Hemicelluloses and pectins? [looking in course notes]

Tutor: Yes, you could say the hemicelluloses and the pectins. Those are the gelling part. But in primary cell walls, the matrix is mainly water. The hemicelluloses and the pectins are more concentrated in the secondary cell walls [writes that the gel matrix can be mainly water, or more gel-like]. So now we're introducing some new concepts. The primary cell wall and the secondary cell wall...

This dialogue is typical of the discussion between the tutor and students (both as individuals and as a whole class), and shows how the tutor tried to elicit student views when building up a concept map, linking new concepts to ones the students had already been introduced to. Recording the ideas in a concept map meant that students had a visual representation of the concepts being discussed, and the linking terms made the relationship between concepts explicit.

\section{Student Perceptions of the Value of Concept Mapping as a Teaching/Learning Tool}

Student responses to the concept mapping tutorials, based on the concept mapping experience questionnaires (see Tables II and III) are now described. Table II reports responses to the concept mapping experience questionnaire in Appendix A after the course in animal and plant biology, and Table III reports responses to the second, modified, questionnaire in Appendix B, after the course in cellular and molecular biology. The responses were analyzed thematically and are reported more fully below. 


\section{TABLE II}

Responses to the concept mapping experience questionnaire (Appendix A), administered in the course on animal and plant biology. Responses were analyzed by theme $(N=27)$

\section{TABLE III}

Responses to the concept mapping experience questionnaire (Appendix B), administered in the course on cellular and molecular biology $(N=35)$

know and what I need to learn more about

I have sometimes used concept mapping for studying biology my other courses

\footnotetext{
${ }^{\text {a }}$ One person did not respond.
} 
TABLE IV

Results for course assessment tasks (see Table I) that were analyzed for cognitive effects of concept mapping

\begin{tabular}{|c|c|c|c|c|c|c|}
\hline \multirow[b]{2}{*}{ Item } & \multicolumn{2}{|c|}{ Concept mapping tutorial } & \multicolumn{2}{|c|}{ Conventional tutorial } & \multicolumn{2}{|c|}{ No tutorial } \\
\hline & $(\mathrm{N})$ & $\begin{array}{l}\text { Expected } \\
\operatorname{answer}^{\mathrm{a}}(\%)\end{array}$ & $(\mathrm{N})$ & $\begin{array}{l}\text { Expected } \\
\text { answer }^{\mathrm{a}}(\%)\end{array}$ & $(\mathrm{N})$ & $\begin{array}{l}\text { Expected } \\
\text { answer }^{\mathrm{a}}(\%)\end{array}$ \\
\hline 1 & 30 & 37 & 35 & 40 & 157 & 43 \\
\hline 2 & 64 & 50 & 49 & 49 & 117 & 40 \\
\hline 3 & 24 & 21 & 14 & 21 & 163 & 19 \\
\hline 4 & 42 & 81 & 26 & 62 & 100 & 73 \\
\hline 5 & 16 & 94 & 12 & 83 & 134 & 85 \\
\hline $6^{* *}$ & 28 & 71 & 46 & 50 & 90 & 40 \\
\hline $7 * *$ & 40 & 80 & 15 & 53 & 115 & 55 \\
\hline $8^{*}$ & 33 & 82 & 23 & 57 & 108 & 37 \\
\hline $9 * *$ & 16 & 88 & 12 & 58 & 134 & 55 \\
\hline $10^{* *}$ & 16 & 94 & 16 & 63 & 176 & 49 \\
\hline
\end{tabular}

${ }^{\mathrm{a}}$ Based on the teacher's marking of the assessment task.

*Difference between 'concept mapping tutorial' and both 'conventional tutorial' and 'no tutorial' is statistically significant $(P<0.05)$.

**Difference between 'concept mapping tutorial' and both the 'conventional tutorial' and 'no tutorial' is statistically significant $(P<0.01)$.

\section{Concept Mapping can be a Useful Tool to Summarize and Learn Course Content}

A common theme to emerge from the data from both courses was that students considered concept mapping to be a good way to study biology, and that they felt it helped them to understand course material (see Tables II and III). For example, Sally wrote, "I have attended other tutorials, but I find the concept mapping tutorials more informative and you learn the content better," and Andrew reported: "I like concept mapping. It's a good way to present information and makes it easier to remember ideas."

In particular, concept mapping was seen as a useful tool for summarizing the large mass of material undergraduate biology students encounter in first year classes: Angus wrote that concept maps "are very good at summarizing the material, as the lecturers often go into detail but it is sometimes hard to put it all together." This comment was echoed by Alister, who wrote: "I really like the concept mapping because it helps eliminate the clutter and 'fluff' terminology," and Jamie wrote, "I think [concept mapping] helps to create an overall map of concepts." 
A large proportion of students also reported using concept mapping for other topics in their biology and other science courses. For example, Olivia wrote: "The mindmaps are very helpful and allow me to create 'quick study' notes of my own ... It has made me use them for other subjects and for other topics in biology." This suggests that at least some students saw concept mapping as a useful learning strategy, and that they applied it to their learning outside of the tutorial classes.

A few students reported, however, that they would have preferred it if the tutor had not answered questions using concept mapping. One of these, Chen, a student from a non-English speaking background (NESB), wrote: "It will be helpful to get ideas how to answer test questions." An assessment focus featured in the comments of four other students who also indicated that they would have preferred to have spent less time on concept mapping, and more time focusing on past test and exam questions. For example, Pang, another international NESB student, wrote: "Concept mapping has helped me learn the material more effectively. However, it didn't help much on how we should answer the test questions."

Brian, another student who appeared to be less enthused about concept mapping, was more insightful, writing: "I don't think you can say that concept mapping suits every aspect of what we are studying. It helps with some examples but for others, tables and charts and other examples might be better." It is worthwhile noting here that this sentiment is in broad agreement with the tutor, who used a mixture of diagrams and concept mapping (e.g., to differentiate between the body plans of different animals), and sometimes just diagrams (e.g., to compare the internal arrangement of monocotyledon and dicotyledon stems).

In summary, the majority of the students who completed the concept mapping experience questionnaire indicated that they felt that concept mapping was a useful way to study biology. Negative case study analysis (Roth, 1994) showed that some students felt that concept mapping may not always be the most suitable way to summarize content (in some cases, for example, annotated biological drawings or 3-D models may be better), and that students may find it frustrating that concept mapping does not give them the 'right' answers to test questions.

\section{Concept Mapping can Help Students to Form Links between Concepts}

The majority of students who completed the concept mapping experience questionnaire indicated that concept mapping had helped them to see links between concepts (see Tables II and III). For example, Sue reported: "The concept maps have helped me as it is easier to understand 
the way bits of a topic link together." Alan wrote, "It is good for tieing [sic] many processes together."

Other students felt that the concept mapping tutorials helped them to understand the lecture content more clearly because the links between concepts are made explicit. For example, Dianna wrote that concept mapping "has definitely helped because in the lectures the concepts were quite 'muddled' and many of the ideas were interrelated." A few students reported that concept mapping requires you to understand which concepts are related. As Renee wrote: "It helps you piece things together and include all the data you need."

In summary, students seemed to consider concept mapping to be a helpful strategy to determine the relationships between concepts and between different conceptual themes.

\section{Student-Constructed Concept Maps}

Many of the respondents to the concept mapping experience questionnaire reported that they had found it helpful to construct concept maps either on their own or with other students (as opposed to the tutor constructing the concept maps). In some cases it seemed that students felt that because the activity was 'hands-on', this facilitated learning. For example, Alex wrote: "Doing them makes you think, therefore learning takes place." Andrew similarly reported that constructing maps with others helped him "to remember the concepts more easily."

Other students indicated that constructing the concept maps on their own or in small groups had helped to highlight problematic areas. For example, Sue wrote: "Doing the mapping myself makes it so I know things that I am unsure of, how they fit into a topic." Oliver wrote, "It highlights gaps in my knowledge that I need to go back to."

The students also valued interaction with the tutor, who circulated around the class whilst the students constructed the maps. For example, Angela wrote: "I thought it was effective by starting us off, giving us time to do it on our own, and then going over them as a whole at the end and explaining the concepts." John wrote: "[The tutor] always comes around to every group to make sure everyone understands," and Olivia observed, "[The tutor] is always willing to field questions about the topics, as well as semi-related topics which I find useful and informative."

In summary, many of the students appreciated the opportunity to work on constructing their own concept maps, reporting that it helped them to engage with the content and identify areas where their 
understanding was weaker. Feedback from the tutor was also considered important. It is, however, worthwhile noting that two students reported that they did not like concept mapping because of the time involved in constructing them.

\section{The Influence of Concept Mapping on Student Learning}

Student achievement on pre-selected items from course assessment tasks (see Table I) was correlated with tutorial attendance (using information about topics covered in tutorials, and tutorial attendance sheets) and analyzed for differences using a chi-square test for independence. The results (see Table IV and Figure 2) show statistically significant differences in student achievement for questions that required students to have an understanding of a range of concepts and the links between them, with students who attended the relevant concept mapping tutorials achieving higher marks than those who attended either a conventional tutorial, or no tutorial. In contrast, there was no difference in responses to questions that did not require a sophisticated level of conceptual organization, but that could be answered by repeating facts found in the student lecture notes.

In other words, differences in student responses only applied to questions that required students to demonstrate links between concepts beyond those that were made explicit in lectures. The content had been discussed in all the tutorials associated with the relevant lecture, although this had been done in a linear fashion in the conventionally-taught tutorials and in a way that encouraged conceptual linking in the concept mapping tutorials.

\section{SUMMARY AND CONCLUSIONS}

The body of literature supporting concept mapping as a teaching and learning strategy is enormous, although many of the studies focus on the use of concept mapping as a tool to investigate student understanding rather than evaluating its usefulness in facilitating student learning. It was therefore of interest to investigate the response of tertiary students to the introduction of concept mapping as a teaching/learning tool.

The first-year biology students involved in the concept mapping tutorial sessions described in this paper were generally positive about the experience, reporting that concept mapping helped them to link concepts together as well as summarize and recall course content. Consistent with the findings reported by others (e.g., Roth, 1994), the majority of students 


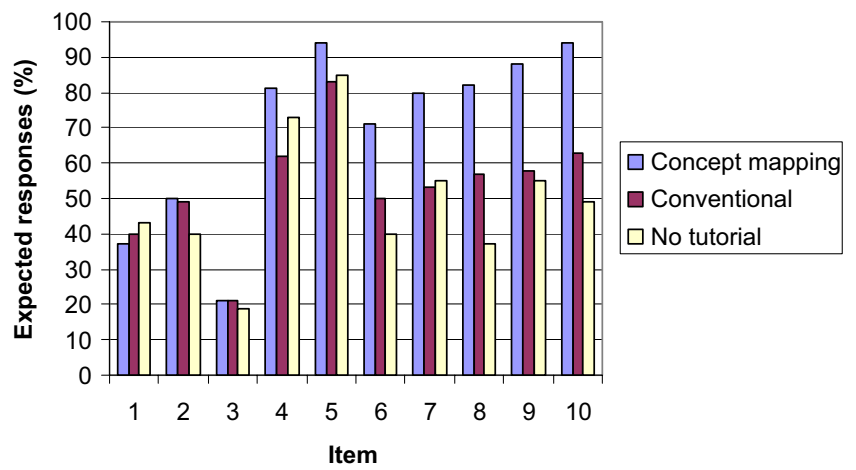

Figure 2. Quantitative responses to selected assessment items (see Table 1). Responses are grouped according to tutorial attendance. Note 1: Sample sizes varied for each question (concept mapping and conventional tutorial samples ranged from 12-64; no tutorial sample ranged from 90-176, see Table IV). Note 2: Statistically significant differences between concept mapping tutorial and both conventional tutorial and no tutorial were seen for questions 6-10 (see Table IV).

indicated that they had found it useful constructing the concept maps on their own or in small groups. The classroom management strategies used in this study also seemed to be significant. The tutor circulated around the classroom discussing with students the concept maps as they were being constructed, and this formative feedback was valued by the students.

The quantitative data suggest that students who had attended concept mapping tutorials were more likely to score higher on traditional assessment tasks that required an understanding of the links between a range of concepts. Concept mapping did not appear to help students perform better on assessment tasks that could be answered using rotelearning strategies. This raised the question about the type of questions that were more dominant in the assessment tasks (i.e., whether rote learning could be used to effectively answer the majority of questions). A few students alluded to this in their reports that although they felt concept mapping had helped them to learn the material, it did not necessarily help them to answer test questions.

\section{DISCUSSION AND IMPLICATIONS FOR TEACHING}

Despite numerous references to concept mapping in the science education literature, very few studies were found that evaluated the effectiveness of concept mapping in tertiary-level biology classrooms. In a study by Heinze-Fry and Novak (1990), college students completed an 
autotutorial course that was self-paced and incorporated concept mapping tasks. Although the authors reported no statistically significant differences in understanding as a result of concept mapping, the authors argue this was because sample size was small and students had had limited exposure to concept mapping as a learning tool. In another study, students were given a short training session in the use of concept mapping and then asked to read a text on the human circulatory system (Smith \& Dwyer, 1995). When their understanding of the text was evaluated, there were no statistically significant differences between the group that had been given an instructor-prepared map to study alongside the text; the group that had been asked to construct their own concept map; and the group that had not been asked to consider concept mapping at all.

The current study differs from these two studies in that students were exposed to the use of concept mapping over a 12-week teaching semester in each of two courses. The use of concept mapping was modeled and feedback on their maps was provided. The study shows that concept mapping can be introduced into tertiary-level tutorial classes and that students are on the whole very positive about its use. Classroom management also was seen to be important. In implementing the use of concept mapping, it was found that there was a need for the teacher to model the construction of concept maps, but that students valued the opportunity to spend time constructing their own maps. The role of the teacher in guiding discussions with the students (both as a whole class and with individual students or small groups of students as they constructed their own concept maps) was also valued, as was a whole class discussion held at the end of each tutorial session in which a range of student-constructed maps could be discussed and feedback (both from the tutor and other class members) could be given.

The current findings also contribute to the broader concept mapping literature by distinguishing between the cognitive effects of concept mapping for different types of tasks (those that require rote memorization and those that entail deeper learning and the linking of several different concepts). Similar findings were reported by Schmid \& Telaro (1990) evaluating the effect of concept mapping use by 9th and 10th graders in Canada, but the majority of research seems to report concept mapping as either having a significant impact on learning, or not. Indeed, some of the studies that report no significant differences as a result of concept mapping might be the result of questions focusing on rote reproduction of responses, rather than tasks that require more sophisticated understanding of concepts. 
The finding that concept mapping is useful only for tasks that require understanding of links between concepts is also important for entry-level biology courses, which tend to focus on presentation of large amounts of content. As Novak (1990) argues, concept mapping "is no 'magic bullet,' no 'quick fix' for classrooms where rote learning predominates." Although we argue that concept mapping is a useful teaching and learning strategy that can effectively be used alongside other strategies in tertiary tutorial classes, this is only true if the type of deep learning that is encouraged through the concept mapping strategy is also the focus of assessment tasks (and ultimately the course objectives). ${ }^{2}$ Students are likely to value strategies that encourage deep learning only if this kind of learning is rewarded. This means that those considering the introduction and use of concept mapping as a teaching and learning tool need to also consider the overall objectives of the course and the type of learning that students are required to do.

Shulman (1997) points out that any educational inquiry possesses some limitations. What is important is to recognize any limitations, and to take appropriate care in interpretation of the meaning of research findings. This study was conducted in a particular educational context, one which we argue like many others is dominated by didactic teaching methods and assessment regimes which seem to reward such pedagogies. We saw some evidence that for some students concept mapping is different to the normal teaching approach. This made them uncomfortable with the approach. Hence, one limitation for our work is that that teaching faculty may encounter student resistance to the use of concept mapping if students are heavily focused on high-stakes assessment regimes that reward rote learning. Our recommendation then is that teachers carefully consider if concept mapping is necessary and appropriate for their own educational setting. Coll (2000) argues that there is often a disconnection between course aims and objectives articulated (or as presented in course outlines) by university teaching staff and the assessment regimes associated with the courses. Because of this, O'Donovan, Price \& Rust (2004) argue that it is crucial that students understand not only the course educational aims, but the assessment regimes (and whether they seek to facilitate meaningful learning). If the course objectives do actually require linking of concepts, then our work here suggests this may be enhanced by the use of concept mapping. If the course objectives and assessment practices do not require students to link concepts then there is probably little point in engaging in what is a fairly time consuming task of developing a new teaching approach. 
The research here examined the use of concept mapping for introductory tertiary, university biology classes. A key focus was the diversity of the class. Future tertiary-level research could seek to deepen our understanding of other disciplines, such as chemistry and physics, other educational contexts, for example, developing countries, and other student cohorts such as the gifted or students with special needs.

\section{APPENDIX A}

Concept mapping experience questionnaire (Semester 1).

1. What do you like about the way this tutorial session is normally run?

2. What would you change about the way this tutorial session is normally run?

3. Please comment specifically on the way that Alison has tried to use concept mapping in this tutorial session. E.g., has it helped you to learn the material more effectively? What did you think of having to do some of the concept mapping yourself?

\section{APPENDIX B}

Concept mapping experience questionnaire (Semester 2).

Please indicate how strongly you agree with each of the following statements about the tutorials:

\begin{tabular}{|c|c|c|c|c|}
\hline & $\begin{array}{l}\text { Strongly } \\
\text { agree }\end{array}$ & Agree & Disagree & $\begin{array}{l}\text { Strongly } \\
\text { disagree }\end{array}$ \\
\hline $\begin{array}{l}\text { a. Concept mapping seems } \\
\text { to be a good way to study } \\
\text { biology }\end{array}$ & $\square$ & $\square$ & $\square$ & $\square$ \\
\hline $\begin{array}{l}\text { b. Concept mapping helped } \\
\text { me to understand the material }\end{array}$ & $\square$ & $\square$ & $\square$ & $\square$ \\
\hline $\begin{array}{l}\text { c. Concept mapping helped me } \\
\text { to see links between concepts }\end{array}$ & $\square$ & $\square$ & $\square$ & $\square$ \\
\hline $\begin{array}{l}\text { d. It is easy to learn how to do } \\
\text { concept mapping }\end{array}$ & $\square$ & $\square$ & $\square$ & $\square$ \\
\hline $\begin{array}{l}\text { e. I found it useful to be able to } \\
\text { work on making a concept map } \\
\text { with other students }\end{array}$ & $\square$ & $\square$ & $\square$ & $\square$ \\
\hline $\begin{array}{l}\text { f. I felt that there was enough time } \\
\text { for me to ask questions during the } \\
\text { tutorials }\end{array}$ & $\square$ & $\square$ & $\square$ & $\square$ \\
\hline
\end{tabular}


(Continued.)

\begin{tabular}{|c|c|c|c|c|}
\hline & $\begin{array}{l}\text { Strongly } \\
\text { agree }\end{array}$ & Agree & Disagree & $\begin{array}{l}\text { Strongly } \\
\text { disagree }\end{array}$ \\
\hline $\begin{array}{l}\text { g. I found that I had to think during } \\
\text { the tutorials }\end{array}$ & $\square$ & $\square$ & $\square$ & $\square$ \\
\hline $\begin{array}{l}\text { h. I felt relaxed in the classroom } \\
\text { environment }\end{array}$ & $\square$ & $\square$ & $\square$ & $\square$ \\
\hline $\begin{array}{l}\text { i. I would have preferred it if Alison } \\
\text { had answered questions without using } \\
\text { concept mapping }\end{array}$ & $\square$ & $\square$ & $\square$ & $\square$ \\
\hline $\begin{array}{l}\text { j. Concept mapping is helpful because it } \\
\text { shows me what I know and what I need to } \\
\text { learn more about }\end{array}$ & $\square$ & $\square$ & $\square$ & $\square$ \\
\hline $\begin{array}{l}\text { k. I have sometimes used concept mapping } \\
\text { for studying biology outside of the tutorials }\end{array}$ & $\square$ & $\square$ & $\square$ & $\square$ \\
\hline $\begin{array}{l}\text { 1. I have sometimes used concept mapping } \\
\text { for studying in my other courses }\end{array}$ & $\square$ & $\square$ & $\square$ & $\square$ \\
\hline
\end{tabular}

Do you have any other comments about concept mapping, or about the tutorial in general?

If you attend other tutorials, which 'style' do you prefer?

\section{NOTES}

${ }^{1}$ Based on a questionnaire administered to students during the first teaching week; response rate $80 \%$.

${ }^{2}$ Coll (2000) suggests that there is not necessarily a strong link between stated course aims and objectives and the assessment regimes associated with the courses.

\section{REFERENCES}

Adamczyk, P., Willison, M. \& Williams, D. (1994). Concept mapping: A multi-level and multi-purpose tool. School Science Review, 76(275), 116-124.

Arnaudin, M.W., Mintzes, J.J., Dunn, C.S. \& Shafer, T.S. (1984). Concept mapping in college science teaching. Journal of College Science Teaching, 14(2), 117-121.

Ausubel, D.P. (1968). Educational psychology: A cognitive view. New York: Hart, Rinehart and Winston. 
Barenholz, H. \& Tamir, P. (1992). A comprehensive use of concept mapping in design instruction and assessment. Research in Science and Technological Education, 10(1), 37-52.

Black, P. (1998). Assessment by teachers and the improvement of students' learning. In B.J. Fraser \& K.G. Tobin (Eds.), International handbook of science education (pp. 811-822). Dordrecht, The Netherlands: Kluwer.

Brandt, L., Elen, J., Hellemans, J., Heerman, L., Couwenberg, I., Volckaert, L. \& Morisse, H. (2001). The impact of concept mapping and visualization on the learning of secondary school chemistry students. International Journal of Science Education, 23(12), 1303-1313.

Brophy, J. (2002). Social constructivist teaching: Affordances and constraints, Vol. 9. Amsterdam: Elsevier Science.

Buntting, C., Coll, R.K. \& Campbell, A. (2004). Introductory biology courses at university: Gaps between lecturer assumptions and student reality. In D.B. Zandvliet (Ed.), Proceedings of the Annual Meeting of the National Association for Research in Science Teaching (pp. 1-19). Vancouver, BC.

Coll, R.K. (1997). Teaching industrial and applied chemistry at the University of Waikato: Using the workplace as the classroom. Education Today, 47(4), 50-53.

Coll, R.K. (2000). Learners' mental models of chemical bonding: A cross-age study. EdD thesis, Curtin University of Technology (available from http://adt.curtin.edu.au/ theses/available/adt-WCU20020513.142708/).

Coll, R.K. (in press). The role of models, mental models and analogy in chemistry and teaching. In P. Aubusson, A. Harrison \& S.M. Ritchie (Eds.), Metaphor and Analogy in Science Education. Dordrecht, The Netherlands: Kluwer.

Coll, R.K., France \& Taylor (2005). The role of models/and analogies in science education: Implications from research. International Journal of Science Education, 27(2), 183-198.

Dalgety, J., Coll, R.K. \& Jones, A. (2003). The development of the Chemistry Attitudes and Experiences Questionnaire (CAEQ). Journal of Research in Science Teaching, 40(7), 649-668.

Dawson, C. (1993). Chemistry in concept. Education in Chemistry, 30(May), 73-75.

Dearing, R. (1997). Report of the inquiry into higher education. London: HSMO.

Douvdevany, O., Dreyfus, A. \& Jungwirth, E. (1997). Diagnostic instruments for determining junior high school science teachers' understanding of functional relationships within the living cell. International Journal of Science Education, 19(5), 593-606.

Erickson, G.L. \& Meyer, K. (1998). Performance assessment tasks in science: What are they measuring? In B.J. Fraser \& K.G. Tobin (Eds.), International handbook of science education (pp. 845-865). Dordrecht, The Netherlands: Kluwer.

Fensham, P.J. (1980). Constraint and autonomy in Australian secondary science education. Journal of Curriculum Studies, 12, 186-206.

Fensham, P.J. (1992). Science education at first degree level. International Journal of Science Education, 14(5), 505-514.

Fisher, K.M., Wandersee, J.H. \& Moody, D.E. (2000). Mapping biology knowledge. Dordrecht, Netherlands: Kluwer. 
Garnett, P.J., Garnett, P.J. \& Hackling, M.W. (1995). Students' alternative conceptions in chemistry: A review of research, and implications for teaching and learning. Studies in Science Education, 25, 69-95.

Gates, S.M., Augistine, C.H., Benjamin, R., Bikson, T.K., Kaganoff, T., Levy, D.G., Moini, J.S. \& Zimmer, R.W. (2002). Ensuring quality and productivity in higher education: An analysis of assessment practices. Retrieved 18 July, 2005 from ERIC Digest, ED468727 2002-00-00.

Gitomer, D.H. \& Duschl, R.A. (1998). Emerging issues and practices in science assessment. In B.J. Fraser \& K.G. Tobin (Eds.), International handbook of science education (pp. 791-810). Dordrecht, The Netherlands: Kluwer.

Good, T. \& Brophy, J. (2000). Looking in classrooms (8th ed.). New York: Addison Wesley Longman.

Good, R.G., Wandersee, J.H. \& St. Julien, J. (1993). Cautionary notes on the appeal of the new 'ism' (constructivism) in science education. In K. Tobin (Ed.), The practice of constructivism in science education (pp.71-87). Hillsdale, NJ: Lawrence Erlbaum.

Guba, E.G. \& Lincoln, Y.S. (1994). Competing paradigms in qualitative research. In N.K. Denzin \& Y.S. Lincoln (Eds.), Handbook of qualitative research (pp.105-117). Thousand Oaks, CA: Sage.

Harrison, A.G. \& Treagust, D.F. (1996). Secondary students' mental models of atoms and molecules: Implications for teaching chemistry. Science Education, 80(5), 509-534.

Harrison, A.G. \& Treagust, D.F. (1998). Modelling in science lessons: Are there better ways to learn with models? School Science and Mathematics, 98(8), 420-429.

Heinze-Fry, J.A. \& Novak, J.D. (1990). Concept mapping brings long-term movement toward meaningful learning. Science Education, 74, 461-472.

Horton, P.B., McConney, A.A., Gallo, M., Woods, A.L., Senn, G.J. \& Hamelin, D. (1993). An investigation of the effectiveness of concept mapping as an instructional tool. Science Education, 77(1), 95-111.

Huai, H. (1997). Concept mapping in learning biology: Theoretical review on cognitive learning styles. Journal of Interactive Learning Research, 8(3/4), 325-340.

Kinchin, I.M. (2000). Concept mapping in biology. Journal of Biological Education, 34(2), 61-68.

Kings, C.B. (1990). Development in science and technology education: Some crosscultural perspectives. The Australian Science Teachers Journal, 36(3), 39-45.

Laugksch, R. (2000). Scientific literacy: A conceptual overview. Science Education, 84(10), 71-94.

Laws, P.M. (1996). Undergraduate science education: A review of research. Studies in Science Education, 28, 1-85.

Lomask, M.S., Baron, J.B. \& Greig, J. (1998). Large-scale science performance assessment in Connecticut: Challenges and resolutions. In B.J. Fraser \& K.G. Tobin (Eds.), International handbook of science education (pp. 823-844). Dordrecht, The Netherlands: Kluwer.

Massey University (2004). 10 year plan. Palmerston North, New Zealand: Massey University. Retrieved 26 February 2004 from http://sfp.massey.ac.nz/Library/ 10\%20Year\%20Plan\%20-word\%20document.doc. 
Merriam, S.B. (2001). Qualitative research and case study applications in education. San Francisco: Jossey-Bass.

Millar, R. (1989). Constructive criticisms. International Journal of Science Education, 11 (special issue), 587-596.

Novak, J.D. (1990). Concept mapping: A useful tool for science education. Journal of Research in Science Teaching, 27(10), 937-949.

Novak, J.D. \& Gowin, D.B. (1984). Concept mapping for meaningful learning. In J.D. Novak \& D.B. Gowin (Eds.) Learning how to learn (pp. 15-54). New York: Cambridge University Press.

O'Donovan, B., Price, M. \& Rust, C. (2004). Know what I mean? Enhancing student understanding of assessment standards and criteria. Teaching in Higher Education, 9(3), 325-335.

Okebukola, P.A. (1992). Can good concept mappers be good problem solvers in science? Educational Psychology, 12(2), 113-129.

Peshkin, A. (1993). The goodness of qualitative research. Educational Researcher, 22(2), 24-30.

Pfundt, H. \& Duit, R. (1997). Bibliography: Students' alternative frameworks and science education (4th ed.). Kiel, Germany: University of Kiel.

Pfundt, H. \& Duit, R. (2000). Bibliography: Students' alternative frameworks and science education (5th ed.). Kiel, Germany: University of Kiel.

Roth, W.-M. (1994). Student views of collaborative concept mapping: An emancipatory research project. Science Education, 78(1), 1-34.

Sade, D. \& Coll, R.K. (2003). Technology and technology education: Views of some Solomon Island primary teachers and curriculum development officers. International Journal of Science and Mathematics Education, 1, 87-114.

Schmid, R.F. \& Telaro, G. (1990). Concept mapping as an instructional strategy for high school biology. Journal of Educational Research, 84, 78-85.

Shulman, L.S. (1997). Disciplines of inquiry in education: A new overview. In R.M. Jaeger (Ed.), Complementary methods for research in education (2nd ed.), (pp. 3-69). Washington, DC: American Educational Research Association.

Sizmur, S. \& Osbourne, J. (1997). Learning processes and collaborative concept mapping. International Journal of Science Education, 19(10), 1117-1135.

Slotte, V. \& Lonka, K. (1999). Spontaneous concept maps aiding the understanding of scientific concepts. International Journal of Science Education, 21, 515-531.

Smith, K.M. \& Dwyer, F.M. (1995). The effect of concept mapping strategies in facilitating student achievement. International Journal of Instructional Media, 22(1), $25-32$.

Taber, K.S. (1995). Development of student understanding: A case study of stability and lability in cognitive structure. Research in Science and Technological Education, 13(1), 89-99.

Taber, K.S. (1998). An alternative conceptual framework from chemistry education. International Journal of Science Education, 20(5), 597-608.

Tamir, P. (1998). Assessment and evaluation in science education: Opportunities to lean and outcomes. In B.J. Fraser \& K.G. Tobin (Eds.), International handbook of science education (pp. 761-789). Dordrecht, The Netherlands: Kluwer. 
Tobin, K. (1993). The practice of constructivism in science education. Hillsdale, NJ: Lawrence Erlbaum.

Trochim, W.M. (1999). The research methods knowledge base (2nd ed.). Cincinnati, OH: Atomic Dog.

University of Waikato (n.d.). Statement of Objectives \& Profile 2003-2005. Retrieved 2 February 2003, from http://www.waikato.ac.nz/profile/.

Vygotsky, L.S. (1962). Thought and language. Cambridge, MA: MIT Press.

Wandersee, J.H. \& Fisher, K.M. (2000). Knowing biology. In K.M. Fisher, J.H. Wandersee \& D.E. Moody, Mapping biology knowledge (pp. 39-54). Dordrecht, Netherlands: Kluwer.

Wandersee, J.H., Mintzes, J.J. \& Novak, J.D. (1994). Research on alternative conceptions in science. In D.L. Gabel (Ed.), Handbook of research on science teaching and learning (pp. 177-210). New York: Macmillan.

Wertsch, J.V. (1985). Vygotsky and the social formation of mind. Massachusetts: Harvard University Press.

White, R. \& Gunstone, R. (1992). Probing understanding. London: Falmer.

Willson, M. \& Williams, D. (1996). Trainee teachers' misunderstandings in chemistry: Diagnosis and evaluation using concept mapping. School Science Review, 770(280), 107-113.

Yarden, H., Marbach-Ad, G. \& Gersoni, J.M. (2004). Using the Concept Map Technique in Teaching Introductory Cell Biology to College Freshman. Paper presented at the annual meeting of National Association for Research in Science Teaching. Vancouver, Canada.

Centre for Science \& Technology Education Research

University of Waikato,

Private Bag 3105, Hillcrest Road,

Hamilton, New Zealand

E-mail:r.coll@waikato.ac.nz 